\title{
ANALYSIS OF THE BEGINNING OF THE EARLY FLIGHT PHASE OF THE SKI JUMP IN ATHLETES WITH DIFFERENT PERFORMANCE LEVELS
}

\author{
Miroslav Janura, Lee Cabell*, Zdeněk Svoboda, Milan Elfmark, Eva Janurová***
}

\author{
Faculty of Physical Culture, Palacký University, Olomouc, Czech Republic \\ * School of Graduate Medical Education - Seton Hall University, South Orange, New Jersey, U.S.A. \\ ** Faculty of Mining and Geology, Technical University of Ostrava, Ostrava, Czech Republic
}

Submitted in September, 2011

BACKGROUND: Obtaining a long jumping distance is necessary in order to succeed among the best competitors in the Nordic combined. The body movement during the take off and early flight is considered to be the most important factor for length of the jump.

OBJECTIVE: The purpose of this study was to assess the technique of the start of the early flight phase among three groups of Nordic combined competitors representing different performance levels, and to compare them with a group of ski jumpers.

METHODS: Thirty competitors from both sport disciplines (Nordic combined and ski jumping), who performed ski jumps using an HS-134 m jumping hill during the 2009 Nordic World Ski Championships in Liberec, were divided into three subgroups based on jump length. Two dimensional kinematic data were collected for the lower extremities, the trunk, and the skis of the competitors.

RESULTS: The elite Nordic combined group showed a greater in-run velocity than did the two other performance groups $(p<.05)$. The center of mass of the elite ski jumpers is shifted more forward in the section $0-5 \mathrm{~m}$ behind the jumping hill edge in comparison with the elite Nordic combined competitors $(p<.05)$. The mediocre-level ski jumpers exhibited higher knee extension angular velocity in this phase of the jump in comparison with the mediocre-level Nordic combined competitors $(\mathrm{p}<.05)$.

CONCLUSIONS: The results indicated that ski jumping competitors took a better aerodynamic position in the section 0-5 $\mathrm{m}$ behind the edge of the jumping hill. The Nordic combined competitors used a higher average in run velocity to achieve ski jump length comparable to those of ski jumpers.

Keywords: Biomechanics, ski jumping, Nordic combined, sport performance, kinematic analysis.

\section{INTRODUCTION}

Nordic combined (NC) is a winter sport divided into two portions: ski jumping (SJ) and cross country ski racing, which differ in their optimum biomechanics, physiology, and body parameters (Burke, 2007). There are fewer studies on NC than on SJ, and the scientific literature related to kinematic analyses of basic jump phases in NC is limited (Janura, Lehnert, Elfmark, \& Vaverka, 1999). While some studies on NC have been published in the biomechanical literature (Jošt \& Pustovrh, 1995), others have been published as part of the literature on muscle physiology and lower limb strength (Bösl, Schwirtz, Rott, \& Großgebauer, 2007; Ereline, 2006; Pääsuke, Ereline, \& Gapeyeva, 2001).

The body movement of the competitor at the jumping hill edge (take off and early flight) is considered the most important factor for good jump execution (Schwameder, 2008). At the end of the take off, the ski jumper engages in a forward rotating body angular momentum, which serves to retain the necessary velocity and the best initial conditions for execution of the early flight position (Schwameder, Müller, Lindenhofer, DeMonte, Potthast, Brüggemann, Virmavirta, Isolehto, \& Komi, 2005).

The kinematics of the execution of the ski jump phases have been analyzed by several investigators. For example, Janura, Elfmark, Seidl, and Vaverka (2001) found that in $\mathrm{NC}$ the best juniors compared to the worst juniors had the center of mass (CoM) more forward behind the edge of the hill and took the flight position earlier, with more effective aerodynamic conditions (smaller drag force). Vaverka, Janura, Elfmark, McPherson, and Puumala (1996) determined that there is a small relationship between the take off kinematic parameters and the length of a jump, which contributes to the large differences among the competitors. The investigators found, however, a larger correlation between the measured angular parameters of the trunk and lower extremities and the length of a jump during a flight $(r=.81)$. Brüggemann, DeMonte, Komi, Isolehto, Müller, Potthast, Schwameder, and Virmavirta 
(2002) found only small differences in competitors' CoM velocities between the best and poor competitors, but did find statistically significant differences between the above-noted groups in knee angular velocity and somersault angle at take off. Jošt, Coh, Pustovrh, and Ulaga (2000) concluded that the best SJs had a large knee angle extension on and behind the hill's edge as well as a tendency for a more pronounced transfer of the hip and the CoM in the anterior direction.

The high requirements of the body at take off (maximum take off force during a short time period) and the complexity of the movement structure result in a high variability of the execution, not only between groups, but also within groups within given performance levels (Janura, Svoboda, \& Uhlár̆, 2007; Vaverka, Janura, Elfmark, Salinger, \& McPherson, 1997). Thus, it is necessary to consider these differences in the comparison of the ski jump execution of the competitors at different performance levels (Arndt, Brügemann, Virmavirta, \& Komi, 1995; Schmölzer \& Müller, 2005).

The purpose of this study was to assess the execution of the start of the early flight phase in the NC among three groups of competitors, representing different skill levels, and to compare them with a group of ski jumpers.

\section{METHODS}

A total of 48 male NC competitors jumped off the large HS-134 m hill (starting gate 37 ) during the 2009 Nordic World Ski Championships in Liberec, the Czech Republic. Of the 48 analyzed competitors, 30 were selected based on the length of the jump (LJ) and were divided into three groups: (1) elite (E; $n=10$, LJ 121-136 m), (2) mediocre (M; $n=10$, LJ 114-118 m), and (3) poor ( $\mathrm{P} ; n=10, \mathrm{LJ} 101-111 \mathrm{~m})$. In addition, of the 72 male ski jumpers participating on the same jumping hill (starting gate 24) the day before, 30 were chosen and divided according the same rules into three groups: ( 1$)$ elite $(\mathrm{E} ; n=10, \mathrm{LJ} 128.5-130 \mathrm{~m})$, (2) mediocre (M; $n=10, \mathrm{LJ} 115.5-117 \mathrm{~m})$, and (3) poor (P; $n=10$, LJ 97-105.5 m).

Video image data were obtained from two digital video cameras $(50 \mathrm{~Hz}$, Sony DCR-TRV 900, Sony, Tokyo, Japan), which were located perpendicular to the sagittal plane of the SJs' movement at early flight (Fig. 1). Because the conditions on the jumping hill did not facilitate the taking of a three dimensional (3D) measurement, we opted for a 2D kinematic analysis in the sagittal plane. The image space was calibrated by a $1 \mathrm{~m}$ arm cross-calibration frame placed in the plane of the movement at the beginning and at the end of the observed section. The length of a recorded sector was $7 \mathrm{~m}$, and the frame had a resolution of $640 \times 480$ pixels, i.e., a shift of the cursor by 1 pixel resulting in a linear resolution of $0.011 \mathrm{~m}$. The accuracy of the body angular values had been quantified in a previous study, in which the magnitude of error for the recorded sector of approximately $1.4 \mathrm{~m}$ was $.51 \%$, and the absolute error was .22\%, respectively (Janura \& Vaverka, 1997).

Fig. 1

The cameras' setup

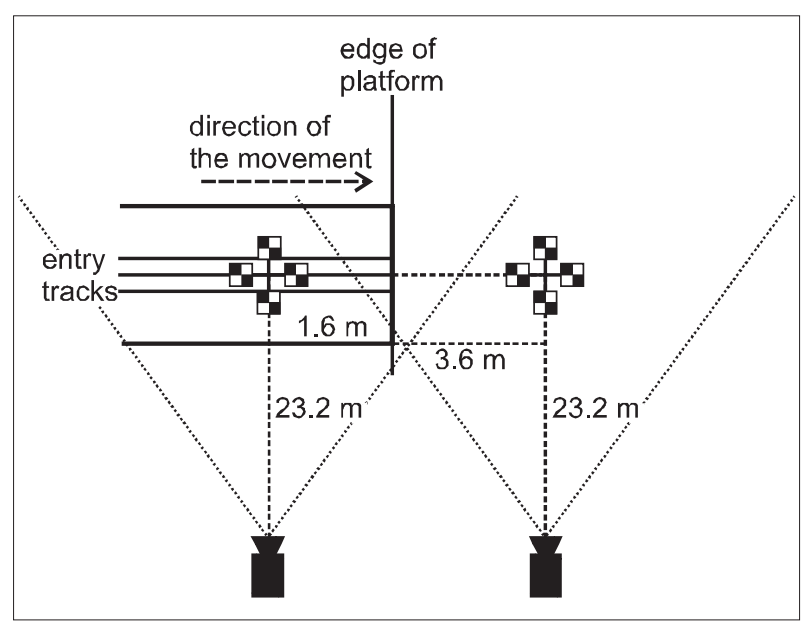

The data were manually digitized (APAS, Ariel Dynamics, Inc., Trabuco Canyon, USA) by an experienced researcher. The origin of the global coordinate system was placed in the middle of the in-run tracks at the jumping hill edge. We assumed a symmetrical jump skier's body position in the sagittal plane. A seven link bilateral model was created based on nine points - the tip and tail of the ski, ankle, knee, hip, top of the head, shoulder, elbow, and wrist. The model included the following segments: foot and shank, thigh, trunk and head, arm, forearm, and jump ski. Data on the segments' relative mass (Karas, Otáhal, \& Sušanka, 1990) were added to the relative mass of the jump skis and ski jumping equipment for the calculation of the CoM.

The average in-run velocities and lengths of jumps were taken from the competitors' official results (18-8 m before the hill's edge). The basic angle parameters of the segments with respect to the horizontal were calculated from the coordinates of the selected points on the SJs' body and the skis in the area $1 \mathrm{~m}$ in front of and $6 \mathrm{~m}$ behind the jumping hill edge (Fig. 2 shows 0 and $5 \mathrm{~m}$ behind the jumping hill edge). The mean joint angular velocity was determined as a ratio of the mean joint angle change and time between the beginning (jumping hill edge) and end ( $5 \mathrm{~m}$ behind the jumping hill edge) of the observed section. The CoM angle was calculated as an angle of the line passing the ankle joint and CoM relative to horizontal. 
Fig. 2

Measured angle parameters

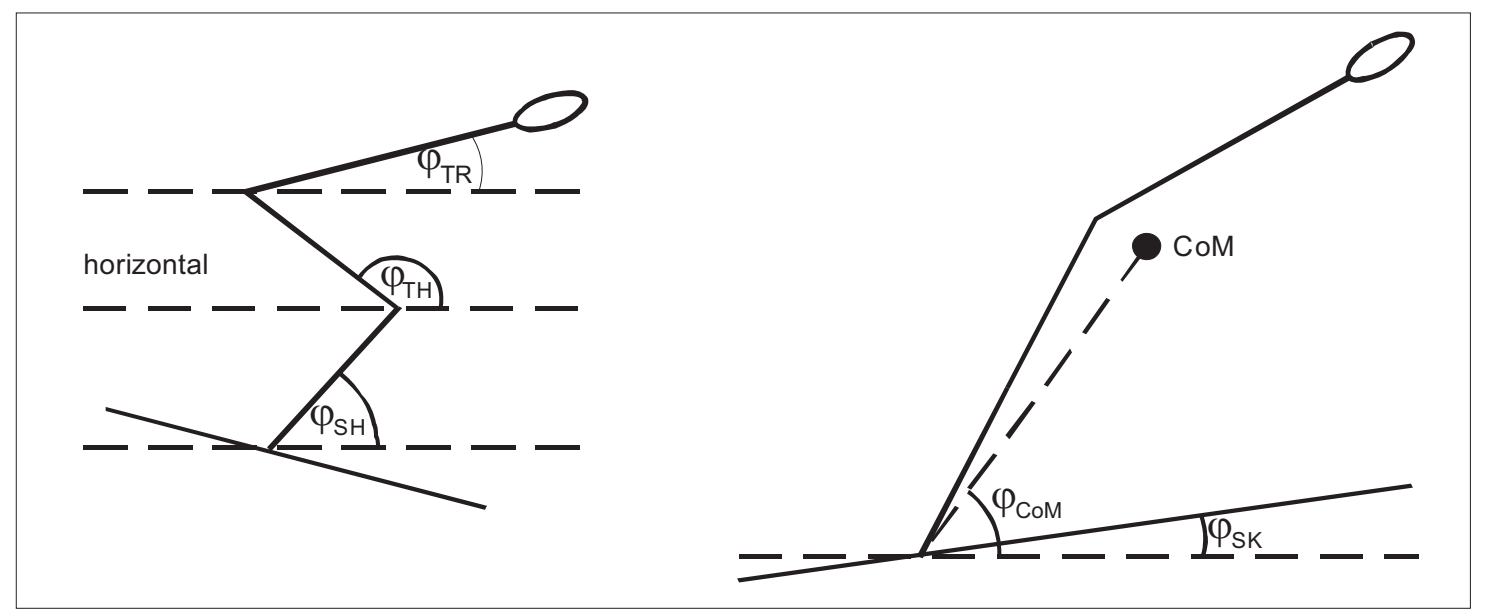

Legend: CoM - center of mass, $\varphi_{\mathrm{TR}}$ - trunk angle to horizontal, $\varphi_{\mathrm{TH}}$ - thigh angle to the horizontal, $\varphi_{\mathrm{SH}}-$ shank angle to horizontal, $\varphi_{\mathrm{SK}}$ - ski angle to horizontal, $\varphi_{\mathrm{CoM}}-$ angle between CoM and ankle connection and horizontal

Two way ANOVA (independent variables are the discipline and performance level) with a Fisher's post-hoc test were performed (Statistica, Version 8.0, Stat-Soft, Inc., Tulsa, USA). The desired power of the test was .80 (Ellis, 2010) for the differences in the variables noted in the study. P-values of less than .05 were deemed to be significant throughout.

\section{RESULTS}

The results of the dependent parameters for the NC and SJ groups in the section from the edge of the jumping hill to $5 \mathrm{~m}$ behind the edge are presented in TABLES 1 and 2.

\section{TABLE 1}

Observed parameters of the NC competitors on the edge and $5 \mathrm{~m}$ behind the jumping hill edge

\begin{tabular}{|c|c|c|c|c|}
\hline & ALL & $\mathbf{E}$ & $\mathbf{M}$ & $\mathbf{P}$ \\
\hline LJ (m) & $116.50 \pm 7.99$ & $126.04 \pm 3.88$ & $116.55 \pm 1.62$ & $106.92 \pm 3.68$ \\
\hline$v\left(m \cdot s^{-1}\right)$ & $26.48 \pm 0.17$ & $26.61 \pm 0.13$ & $26.46 \pm 0.17$ & $26.37 \pm 0.12$ \\
\hline$\varphi_{\mathrm{TR}} \mathbf{0}\left({ }^{\circ}\right)$ & $15.05 \pm 4.50$ & $14.74 \pm 2.92$ & $15.10 \pm 5.99$ & $15.31 \pm 4.74$ \\
\hline$\varphi_{\mathrm{TR}} 5\left(^{\circ}\right)$ & $26.35 \pm 4.57$ & $25.32 \pm 3.39$ & $25.21 \pm 5.24$ & $28.51 \pm 5.17$ \\
\hline$\omega_{\mathrm{TR}}\left({ }^{\circ} \cdot \mathrm{s}^{-1}\right)$ & $57.48 \pm 22.48$ & $54.15 \pm 21.30$ & $51.29 \pm 22.99$ & $67.00 \pm 23.94$ \\
\hline$\varphi_{\mathrm{TH}} \mathbf{0}\left({ }^{\circ}\right)$ & $102.59 \pm 5.14$ & $102.42 \pm 6.20$ & $102.43 \pm 3.31$ & $102.91 \pm 6.40$ \\
\hline$\varphi_{\mathrm{TH}} 5\left(^{\circ}\right)$ & $59.58 \pm 4.86$ & $59.93 \pm 5.04$ & $60.84 \pm 4.83$ & $57.98 \pm 4.82$ \\
\hline$\omega_{\mathrm{TH}}\left({ }^{\circ} \cdot \mathrm{s}^{-1}\right)$ & $222.34 \pm 34.11$ & $217.64 \pm 43.45$ & $221.41 \pm 30.45$ & $227.96 \pm 17.16$ \\
\hline$\varphi_{\mathrm{SH}} \mathbf{0}\left(^{\circ}\right)$ & $55.39 \pm 4.42$ & $55.61 \pm 4.41$ & $55.13 \pm 4.97$ & $55.42 \pm 4.84$ \\
\hline$\varphi_{\mathrm{SH}} 5\left(^{\circ}\right)$ & $59.01 \pm 4.55$ & $60.63 \pm 4.09$ & $59.29 \pm 3.44$ & $57.11 \pm 6.23$ \\
\hline$\omega_{\mathrm{SH}}\left({ }^{\circ} \cdot \mathrm{s}^{-1}\right)$ & $18.51 \pm 28.68$ & $25.74 \pm 30.36$ & $21.24 \pm 26.34$ & $8.54 \pm 30.86$ \\
\hline$\varphi_{\mathrm{SK}} 5\left(^{\circ}\right)$ & $0.58 \pm 4.83$ & $1.13 \pm 3.78$ & $-0.36 \pm 4.54$ & $1.2 \pm 7.39$ \\
\hline$\omega_{\mathrm{SK}}\left({ }^{\circ} \cdot \mathrm{s}^{-1}\right)$ & $54.64 \pm 23.95$ & $52.49 \pm 19.62$ & $59.28 \pm 23.10$ & $50.45 \pm 34.91$ \\
\hline$\varphi_{\mathrm{COM}} \mathbf{0}\left(^{\circ}\right)$ & $60.42 \pm 3.38$ & $60.30 \pm 2.77$ & $60.27 \pm 4.38$ & $60.69 \pm 2.91$ \\
\hline$\varphi_{\mathrm{CoM}} 5\left(^{\circ}\right)$ & $50.88 \pm 3.12$ & $51.19 \pm 3.05$ & $51.14 \pm 3.05$ & $50.32 \pm 3.84$ \\
\hline$\omega_{\mathrm{CoM}}\left({ }^{\circ} \cdot \mathbf{s}^{-1}\right)$ & $47.04 \pm 17.14$ & $46.67 \pm 15.17$ & $46.43 \pm 20.66$ & $52.65 \pm 15.84$ \\
\hline
\end{tabular}

Legend: LJ - length of jump, $\mathrm{v}$ - in-run velocity, $\varphi_{\mathrm{TR}}$ - trunk angle to horizontal, $\varphi_{\mathrm{TH}}$ - thigh angle to the horizontal, $\varphi_{\mathrm{SH}}-$ shank angle to horizontal, $\varphi_{\mathrm{SK}}$ - ski angle to horizontal, $\varphi_{\mathrm{CoM}}$ - angle between CoM and ankle connection and horizontal, $\omega_{\mathrm{TR}}$ - trunk angular velocity, $\omega_{\mathrm{TH}}$ - thigh angular velocity, $\omega_{\mathrm{SH}}$ - shank angular velocity, $\omega_{\mathrm{SK}}$ - ski angular velocity, $\omega_{\mathrm{CoM}}-$ CoM angular velocity, 0 - jumping hill edge, 5 - $\mathrm{m}$ behind the jumping hill edge, $\mathrm{E}$ - elite, $\mathrm{M}$ - mediocre, $\mathrm{P}$ - poor 
TABLE 2

Observed parameters of the SJ competitors on the edge and $5 \mathrm{~m}$ behind the jumping hill edge

\begin{tabular}{|c|c|c|c|c|}
\hline & ALL & $\mathbf{E}$ & $\mathbf{M}$ & $\mathbf{P}$ \\
\hline LJ (m) & $116.26 \pm 7.99$ & $130.80 \pm 2.15$ & $116.00 \pm 0.59$ & $102.00 \pm 2.83$ \\
\hline$v\left(m \cdot s^{-1}\right)$ & $25.68 \pm 0.17$ & $25.75 \pm 0.10$ & $25.75 \pm 0.08$ & $25.64 \pm 0.11$ \\
\hline$\varphi_{\mathrm{TR}} 0\left(^{\circ}\right)$ & $15.68 \pm 4.43$ & $14.94 \pm 4.38$ & $15.62 \pm 4.89$ & $16.49 \pm 4.33$ \\
\hline$\varphi_{\mathrm{TR}} 5\left(^{\circ}\right)$ & $25.11 \pm 4.84$ & $24.72 \pm 4.65$ & $26.91 \pm 5.47$ & $23.71 \pm 4.25$ \\
\hline$\omega_{\mathrm{TR}}\left({ }^{\circ} \cdot \mathrm{s}^{-1}\right)$ & $49.74 \pm 28.95$ & $51.64 \pm 20.67$ & $59.57 \pm 25.79$ & $38.00 \pm 36.66$ \\
\hline$\varphi_{\mathrm{TH}} 0\left(^{\circ}\right)$ & $103.43 \pm 5.60$ & $101.46 \pm 3.47$ & $105.99 \pm 5.15$ & $102.85 \pm 7.10$ \\
\hline$\varphi_{\mathrm{TH}} 5\left(^{\circ}\right)$ & $58.97 \pm 5.61$ & $55.21 \pm 6.30$ & $58.68 \pm 4.19$ & $63.02 \pm 3.17$ \\
\hline$\omega_{\mathrm{TH}}\left({ }^{\circ} \cdot \mathrm{s}^{-1}\right)$ & $234.37 \pm 32.18$ & $244.04 \pm 29.88$ & $249.61 \pm 23.49$ & $209.46 \pm 28.99$ \\
\hline$\varphi_{\mathrm{SH}} 0\left(^{\circ}\right)$ & $52.07 \pm 4.51$ & $51.45 \pm 3.90$ & $52.11 \pm 5.19$ & $52.64 \pm 4.75$ \\
\hline$\varphi_{\mathrm{SH}} 5\left(^{\circ}\right)$ & $58.22 \pm 5.30$ & $56.14 \pm 5.56$ & $57.67 \pm 4.99$ & $60.85 \pm 4.69$ \\
\hline$\omega_{\mathrm{SH}}\left({ }^{\circ} \cdot \mathrm{s}^{-1}\right)$ & $32.47 \pm 31.93$ & $24.83 \pm 28.11$ & $29.29 \pm 36.59$ & $43.29 \pm 30.82$ \\
\hline$\varphi_{\mathrm{SK}} 5\left(^{\circ}\right)$ & $3.20 \pm 4.87$ & $3.63 \pm 4.62$ & $1.56 \pm 3.99$ & $4.40 \pm 5.85$ \\
\hline$\omega_{\mathrm{SK}}\left({ }^{\circ} \cdot \mathrm{s}^{-1}\right)$ & $46.90 \pm 26.42$ & $43.97 \pm 25.04$ & $55.44 \pm 22.21$ & $41.30 \pm 31.67$ \\
\hline$\varphi_{\mathrm{CoM}} \mathbf{0}\left({ }^{\circ}\right)$ & $59.16 \pm 3.24$ & $57.87 \pm 3.72$ & $59.88 \pm 2.41$ & $59.74 \pm 3.38$ \\
\hline$\varphi_{\mathrm{CoM}} 5\left(^{\circ}\right)$ & $50.23 \pm 4.31$ & $47.50 \pm 4.19$ & $50.91 \pm 4.03$ & $52.28 \pm 3.55$ \\
\hline$\omega_{\mathrm{CoM}}\left({ }^{\circ} \cdot \mathbf{s}^{-1}\right)$ & $47.05 \pm 19.92$ & $54.64 \pm 23.27$ & $47.34 \pm 17.32$ & $39.19 \pm 17.44$ \\
\hline
\end{tabular}

Legend: LJ - length of jump, $v$ - in-run velocity, $\varphi_{\mathrm{TR}}$ - trunk angle to horizontal, $\varphi_{\mathrm{TH}}$ - thigh angle to the horizontal, $\varphi_{\mathrm{SH}}-$ shank angle to horizontal, $\varphi_{\mathrm{SK}}$ - ski angle to horizontal, $\varphi_{\mathrm{COM}}$ - angle between CoM and ankle connection and horizontal, $\omega_{\mathrm{TR}}$ - trunk angular velocity, $\omega_{\mathrm{TH}}$ - thigh angular velocity, $\omega_{\mathrm{SH}}$ - shank angular velocity, $\omega_{\mathrm{SK}}$ - ski angular velocity, $\omega_{\mathrm{CoM}}-$ CoM angular velocity, 0 - jumping hill edge, 5 - $\mathrm{m}$ behind the jumping hill edge, $\mathrm{E}$ - elite, $\mathrm{M}$ - mediocre, $\mathrm{P}$ - poor

\section{Comparison of the NC competitors with different perform- ance levels}

With the exception of the average in run velocity, we did not find any significant differences among the different level groups. Specifically, group E had a higher average in run velocity than did group $\mathrm{P}(p<.01)$ or group $\mathrm{M}(p<.05)$.

\section{Comparison of the NC and SJ competitors}

The average in-run velocity was higher in NC group $(p<.01)$. The SJ group experienced a smaller shank angle to the horizontal $(p<.05)$ at the edge of the hill and a higher knee extension angular velocity $(p<.05)$ $5 \mathrm{~m}$ behind the edge of the hill when compared to the NC group. A comparison of the observed NC and SJ groups is presented in Fig. 3.

\section{Fig. 3}

Graphic comparisons of the analyzed groups of NC and SJ competitors at selected points of the analysed area

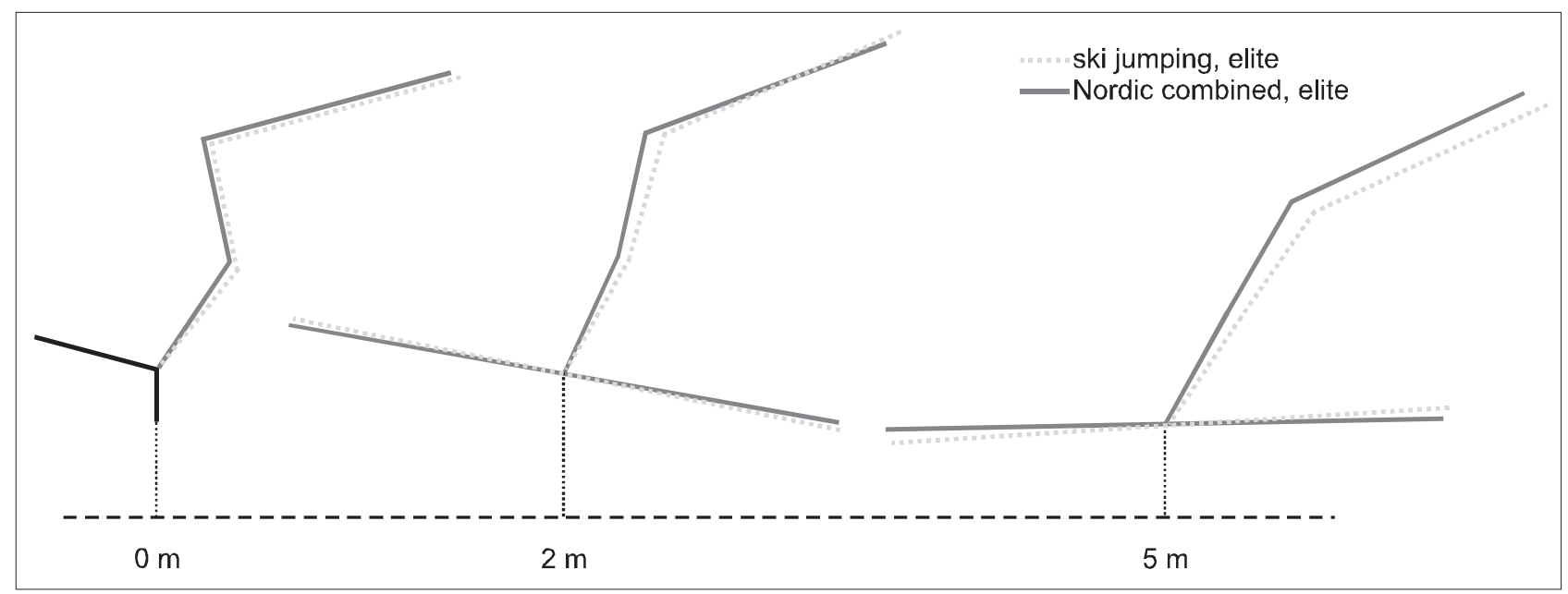


Group E - ski jumpers had a smaller shank angle to the horizontal $(p<.05)$, smaller CoM angle $(p<.01)$, and larger magnitude of the knee extension angular velocity characterized by the shift of the thigh anteriorly $(p<.05)$ in the section $0-5 \mathrm{~m}$ behind the edge.

Group $\mathrm{M}$ - the SJ group exhibited a faster knee extension angular velocity $(p<.01)$ in the section between 0 and $5 \mathrm{~m}$ behind the hill's edge.

Group P - the significant differences were not found between NC and SJ groups.

\section{DISCUSSION}

\section{Comparison of the NC competitors of different perform- ance levels}

With the exception of the magnitude of the in-run velocity, which was larger among the E competitors, we did not find any significant differences in angular and linear parameters. This lack of a significant difference might have been caused by the elite level athletes' correct in-run body position, which is one of the factors that maximize the in-run velocity (Komi, Nelson, \& Pulli, 1974; Vaverka, 1987). The significant influence of the in-run velocity on the length of jump was found in the final round of the 2006 Olympic ski jumping competition in Torino, Italy (Virmavirta, Isolehto, Komi, Schwameder, Pigozzi, \& Massazza, 2009). Dissimilarities in the execution of the jump at the early flight phase were found among the jumpers with similar lengths of jumps; therefore, it is necessary to study individual differences within these groups. The correlations between the measured body parameters and the length of each jump suggest the optimal solution for each jumper (Virmavirta, Isolehto, Komi, Brüggemann, Müller, \& Schwameder, 2005).

\section{Comparison of the NC competitors and the SJ group}

The SJ group had a smaller ankle angle to the horizontal at the jumping hill edge, which might have given the ski jumpers a better body position, minimizing air resistance, for the following rotation and flight body position. This group also exhibited higher explosiveness in the knee joint, supported by the higher knee extension angular velocity $5 \mathrm{~m}$ behind the edge of the hill, which is comparable to the findings of Arndt et al. (1995), who reported similar results as measured at the jumping hill edge. Janura et al. (1999), in contrast, conducted a study with the Czech Republic's teams to compare competitors in different age categories and found that the SJ group had a large ankle angle to the horizontal along with a small knee extension of the angular velocity at the jumping hill edge. Their findings, however, might have been influenced by differences in performance between groups at varying levels.
In run velocity is the key parameter for comparing both ski jumping disciplines. The NC competitors, with high average in run velocities, showed body movement patterns similar to those observed in SJ groups. This higher in-run velocity eliminates differences between both disciplines in training methods and in somatic parameters of competitors.

The fact that the NC competitors had a higher in-run velocity provided them with the potential to jump as far as the SJ group could. Smaller ankle angle to the horizontal by ski jumpers moved the shank more anteriorly and provided the opportunity for a better aerodynamic ski jumping body position. The higher knee extension of the angular velocity executed by the SJ group could have been caused by the fact that ski jumpers concentrate on muscular strength and explosive power training more than Nordic Combined skiiers, who focus on endurance training, which decreases muscle explosiveness (Bösl et al., 2007; Shephard \& Astrand, 1992; Zatsiorsky, 1995). Therefore, it is necessary to utilize a set of internal preconditions for competitors in ski jumping analyses (e.g. anthropometric segment parameters and morphological entries).

\section{Limitations}

The ski jump events in NC and SJ were held on different days, but the weather conditions were comparable, i.e., the air temperature (between $1{ }^{\circ} \mathrm{C}$ and $2{ }^{\circ} \mathrm{C}$ ), snow temperature $\left(-8^{\circ} \mathrm{C}\right.$ in both events), wind velocity (0.2-2.7 m.s $\mathrm{s}^{-1}$ vs. $\left.0.3-2.5 \mathrm{~m} . \mathrm{s}^{-1}\right)$, and wind direction. A possible negative influence of the external conditions was also eliminated by the fact that the competitors, who were, over the long term, characterized by good performance, were excluded from the measurement when they jumped badly.

In run velocity was significantly influenced by a different starting gate in the NC (gate 37) and SJ (gate 24) events.

\section{CONCLUSIONS}

- Among the NC groups no significant differences were found, with the exception of the average in run velocity. The in run velocity of the elite competitors was significantly higher than in both other groups.

- Ski jumpers took a better aerodynamic position in Section 0-5 $\mathrm{m}$ behind the edge of the jumping hill, characterized by a large shift of the shank and center of mass anteriorly.

- In order to compensate for their muscular power and anthropometric disadvantages, Nordic combined competitors have to use higher in-run velocity to achieve ski jump length comparable to those of ski jumpers. 


\section{ACKNOWLEDGEMENT}

The study has been supported by the research grant from the Ministry of Education, Youth and Sports of the Czech Republic (No. MSM 6198959221) "Physical Activity and Inactivity of the Inhabitants of the Czech Republic in the Context of Behavioral Changes".

\section{REFERENCES}

Arndt, A., Brügemann, G.-P., Virmavirta, M., \& Komi, P. V. (1995). Techniques used by Olympic ski jumpers in the transition from take off to early flight. Journal of Applied Biomechanics, 11(2), 224-237.

Bösl, P., Schwirtz, A., Rott F., \& Großgebauer, J. (2007). Comparison of lower limb strength between athletes in ski jumping and Nordic combined. In V. Linnamo, P. V. Komi, \& E. Müller (Eds.), Science and Nordic Skiing (pp. 183-190). Oxford: Meyer \& Meyer Sport Ltd.

Brüggemann, G.-P., DeMonte, G., Komi, P. V., Isolehto, J., Müller, E., Potthast, W., Schwameder, H., \& Virmavirta, M. (2002). Biomechanical analysis of the take off, the early and the mid flight phases in ski jumping during the Salt Lake City Winter Games. Medicine \& Science in Sports \& Exercise, 34(5), 123.

Burke, L. (2007). Practical sports nutrition. Champaign, IL: Human Kinetics.

Ellis, P. D. (2010). The essential guide to effect sizes: An introduction to statistical power, meta-analysis and the interpretation of research results. Cambridge: Cambridge University Press.

Ereline, J. (2006). Contractile properties of human skeletal muscles: Association with sports training, fatigue and post-tetanic potentiation. Doctoral dissertation, Tartu, Tartu University.

Janura, M., Elfmark, M., Seidl, V., \& Vaverka, F. (2001). Analýza skoku na lyžích závodníků v severské kombinaci - MSJ Štrbské Pleso 2000. In H. Válková \& Z. Hanelová (Eds.), Pohyb a zdraví: sborník z 2. mezinárodní konference (pp. 218-221). Olomouc: Univerzita Palackého.

Janura, M., Lehnert, M., Elfmark, M., \& Vaverka, F. (1999). A comparison of the take off and the transition phase of the ski jumping between the group of the ski jumpers and the competitors in Nordic combined. Acta Universitatis Palackianae Olomucensis. Gymnica, 29(2), 7-13.

Janura, M., Svoboda, Z., \& Uhlář, R. (2007). A comparison of ski jump execution in a group of the best jumpers. In V. Linnamo, P. V. Komi, \& E. Müller (Eds.), Science and Nordic skiing (pp. 205-214). Oxford: Meyer \& Meyer Sport Ltd.
Janura, M., \& Vaverka, F. (1997). Hodnocení systému pro analýzu videozáznamu I. (přesnost vyhodnocených dat). Telesná výchova a šport, 7(3), 28-31.

Jošt, B., Čoh, M., Pustovrh, J., \& Ulaga, M. (2000). Analysis of the selected kinematic variables of the take off in ski jumps and their correlation with the length in the finals of the world cup at Planica in 1999. In M. Čoh \& B. Jošt (Eds.), Biomechanical characteristics of technique in certain chosen sports (pp. 58-71). Ljubljana: University of Ljubljana.

Jošt, B., \& Pustovrh, J. (1995). Nordijsko smučanje. Ljubljana: University of Ljubljana.

Karas, V., Otáhal, S., \& Sušanka, P. (1990). Biomechanika tělesných cvičení. Praha: SPN.

Komi, P. V., Nelson, R. C., \& Pulli, M. (1974). Biomechanics of ski jumping. Studies in Sport Physical Education and Health, 5, 1-53.

Pääsuke, M., Ereline, J., \& Gapeyeva, H. (2001). Knee extension strength and vertical jumping performance in Nordic combined athletes. Journal of Sport Medicine and Physical Fitness, 41(3), 354-361.

Schmölzer, B., \& Müller, W. (2005). Individual flight styles in ski jumping: Results obtained during Olympic Games competitions. Journal of Biomechanics, 38(5), 1055-1065.

Schwameder, H. (2008). Biomechanics research in ski jumping - 1991-2006. Sports Biomechanics, 7(1), 114-136.

Schwameder, H., Müller, E., Lindenhofer, E., DeMonte, G., Potthast, W., Brüggemann, P., Virmavirta, M., Isolehto, J., \& Komi, P. (2005). Kinematic characteristics of the early flight phase in ski jumping. In E. Müller, D. Bacharach, R. Klika, S. Lindinger, \& H. Schwameder (Eds.), Science and skiing III (pp. 381-391). Oxford: Meyer \& Meyer Sport.

Shephard, R. J., \& Astrand, P. O. (1992). Endurance in sport. Champaign, IL: Human Kinetics.

Vaverka, F. (1987). Biomechanika skoku na lyžích. Olomouc: Univerzita Palackého.

Vaverka, F., Janura, M., Elfmark, M., McPherson, M., \& Puumala, R. (1996). A general versus individual model of ski jumping technique. In J. M. C. S. Abrantes (Ed.), Proceedings of the XIV ISBS Symposium (pp. 293-296). Funchal-Madeira: Edicoes FMH.

Vaverka, F., Janura, M., Elfmark, M., Salinger, J., \& McPherson, M. (1997). Inter and intra-individual variability of the ski jumper's take off. In E. Müller, H. Schwameder, E. Kornexl, \& C. Raschner (Eds.), Science and skiing (pp. 61-71). London: E \& FN Spo.

Virmavirta, M., Isolehto, J., Komi, P. V., Brüggemann, G. P., Müller, E., \& Schwameder, H. (2005). Characteristics of the early flight phase in the Olympic ski jumping competition. Journal of Biomechanics, 38(11), 2157-2163. 
Virmavirta, M., Isolehto, J., Komi, P. V., Schwameder, H., Pigozzi, F., \& Massazza, G. (2009). Take off analysis of the Olympic ski jumping competition (HS-106m). Journal of Biomechanics, 42(8), 1095-1101.

Zatsiorsky, V. M. (1995). Science and practice of strength training. Champaign, IL: Human Kinetics.

\section{ANALÝZA FÁZE PŘECHODU DO LETU VE SKOKU NA LYŽÍCH U SKUPIN ZÁVODNÍKŮ S RŮZNOU VÝKONNOSTÍ}

(Souhrn anglického textu)

VÝCHODISKA: Dosažení kvalitního výkonu ve skoku na lyžích je nezbytným předpokladem pro výsledné umístění v závodech severské kombinace. Za rozhodující pro provedení skoku na lyžích bývá označována fáze odrazu a následného přechodu do letu. Kinematická analýza těchto fází skoku pro skokany na lyžích byla provedena mnoha autory. Pro závodníky v severské kombinaci je počet výstupů minimální.

Vysoké požadavky na provedení pohybu v odrazové fázi skoku (maximální síla odrazu, extrémně krátký čas realizace) způsobují, při různých antropomotorických parametrech skokanů, vysokou interindividuální variabilitu provedení nejen mezi závodníky s různou výkonností, ale i uvnitř skupin se srovnatelnou délkou skoku.

CÍLE: Cílem studie bylo porovnat provedení zahájení přechodové fáze skoku mezi skupinami závodníků v severské kombinaci s různou výkonností. Určit rozdíly v provedení této fáze skoku mezi závodníky v severské kombinaci a ve skoku na lyžích.

METODIKA: Odrazová a přechodová fáze skoku na můstku HS-134 m při závodech MS v klasickém lyžování v Liberci v r. 2009 byla zaznamenána s využitím tři kamer $(50 \mathrm{~Hz})$. Kamery byly umístěny tak, že jejich optické osy byly kolmé na rovinu pohybu závodníků. Vybrané body na těle a na lyžích závodníků byly vyhodnoceny manuálně. Ze souřadnic těchto bodů jsme určili základní úhlové a rychlostní charakteristiky pro polohu segmentů a lyží. Ze všech startujících závodníků v severské kombinaci jsme vybrali a porovnali skupiny, které dosáhly nejlepší $(B)$, průměrné $(\mathrm{M})$ a nejkratší $(\mathrm{P})$ délky skoku.

VÝSLEDKY: Nájezdová rychlost byla při porovnání skupiny závodníků severské kombinace (NC) a skoku na lyžích (SJ) významně vyšší u skupiny $\mathrm{NC}(\mathrm{p}<0,01)$. Skupina SJ měla na hraně můstku větší posun těla dopředu $(\mathrm{p}<0,05)$. Velikost úhlové rychlosti v kolenním kloubu v úseku 0 až $5 \mathrm{~m}$ za hranou můstku byla vyšší u skupiny $\mathrm{SJ}(\mathrm{p}<0,05)$.

Při porovnání skupin nejlepších závodníků v obou disciplínách byl nalezen rozdíl v poloze bérců na hraně můstku i v celém úseku za hranou. Skupina SJ se vyzna- čovala větším posunem dolních končetin dopředu (hrana, $\mathrm{p}<0,05 ; 5 \mathrm{~m}$ za hranou, $\mathrm{p}<0,01$ ), úhlová rychlost v kolenním kloubu byla vyšší. V tomto parametru jsme také zjistili rozdíl mezi skupinami závodníků s průměrnou výkonností, s větší úhlovou rychlostí u skupiny SJ $(\mathrm{p}<0,05)$.

ZÁVĚRY: Závodníci ve skoku na lyžích mají ve sledovaném úseku za hranou můstku výhodnější aerodynamickou polohu těla, s výraznějším posunem těžiště dopředu. Závodníci v severské kombinaci dosahují srovnatelnou délku skoku se skokany na lyžích, při významně vyšší nájezdové rychlosti.

Kličová slova: biomechanika, skok na lyžích, severská kombinace, sportovní výkon, kinematická analýza.

\section{Prof. RNDr. Miroslav Janura, Dr.}

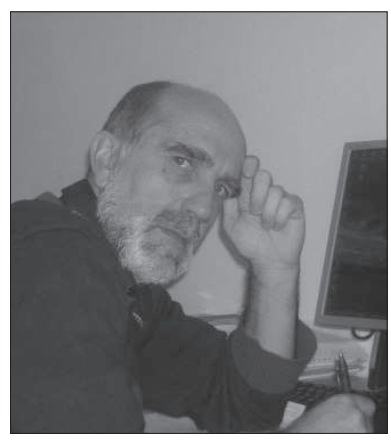

Palacký University, Olomouc Faculty of Physical Culture tř. Míru 115

77111 Olomouc

Czech Republic

Education and previous work experience

1992-1996 - Ph.D. study program at Faculty of Physical Culture.

Foreign study visits - 1995 Lakehead University, Thunder Bay, Canada; 1996 Faculty of Sport, University of Ljubljana, Slovenia; 1998 Faculdade Motricidade Humana Lisabon, Portugal; 2003 Strathclyde University, Glasgow.

\section{First-line publication}

Janura, M., Cabell, L., Elfmark, M., \& Vaverka, F. (2010). Kinematic characteristics of the ski jump inrun: A 10 year longitudinal study. Journal of Applied Biomechanics, 26(2), 196-204.

Janura, M., Dvořáková, T., Peham, Ch., Svoboda, Z., \& Elfmark, M. (2010). The influence of walking speed on equine back motion in relation to hippotherapy. Veterinary Medicine Austria, 97, 87-91.

Janura, M., Cabell, L., Svoboda, Z., Elfmark, M., \& Zahálka, F. (2011). Kinematic analysis of the take off and start of the early flight phase on a large hill (HS-134 m) during the 2009 Nordic World Ski Championships. Journal of Human Kinetics, 27(1), 5-16. 